\title{
COACHING OF CREATING MANGROVE FOREST MOTIF MUARA GEMBONG AS A SOURCE OF BEKASI BATIK MOTIF IDEAS
}

\author{
Muhammad Imam TOBRONI ${ }^{* *}$, Hagung Kuntjara Sambada WIJASA ${ }^{2}$, and Sambudi HAMALI ${ }^{3}$ \\ ${ }^{1}$ Visual Communication Design, School of Design (SOD), Bina Nusantara University Jakarta, Indonesia \\ ${ }^{2,3}$ Management Department, BINUS Business School Undergraduate Program, Bina Nusantara University \\ Jakarta, Indonesia \\ *brony@binus.ac.id
}

\begin{abstract}
Bekasi Regency has beautiful sea views and the existence of a stretch of mangrove forest, namely in Muara Gembong. Currently, Bekasi Regency does not have a typical Bekasi Regency motif as a regional characteristic. The potential of the mangrove forest can be used as a theme in the creation of a distinctive Bekasi motif design. The purpose of this community service is to create new, unique, creative, and innovative batik motifs based on the theme of the Muara Gembong mangrove forest, Bekasi, through graphic design training for students of Tunas Jakasampurna Vocational High School, Bekasi. The method of community service uses the Direct Coaching \& Monitoring method. Of the nine students who were trained, one of the best designs was selected to be used as a sample in prototype training through screen printing technology and direct to the garment in the form of batik cloth and various forms of products. The results of this community service are expected to be Vocational High School students as motivators for Bekasi Micro, Small \& Medium Enterprises (MSME) products and even encourage the creation of new products from Bekasi MSMEs.
\end{abstract}

Keywords: Batik Motif Design; Muara Gombong Mangrove Forest; SMK Tunas Jakasampurna, Bekasi Regency, Various Forms Of Products

\section{BACKGROUND}

Bekasi Regency is one of the regencies in West Java, with the driving force of economic growth is the manufacturing sector. In 2020, the manufacturing industry's contribution to the total GRDP of Bekasi Regency was 77.20 percent, and has a role of 27.95 percent of the total regencies/cities in West Java with a value of Rp. 245.44 trillion (BPS Kabupaten Bekasi, 2021). The Textile and Apparel Industry is a sub-category of the processing industry as the second-largest contributor in West Java (BPS Jabar, 2021). However, for Bekasi Regency, it seems that there is still a lack of this industry. To encourage the creation of community economic opportunities in the textile and apparel industry in Bekasi Regency, one of them is by creating a design motif/pattern design as a Typical Motif of Bekasi Regency. This will open opportunities for MSME actors in Bekasi to develop products in the textile and apparel industry.

According to Suhersono (2004), motifs are designs made from parts of shapes, various kinds of lines, or elements that are influenced by the form of natural stylization, objects with their own style and characteristics. Bekasi Regency has beautiful sea views and the existence of a stretch of mangrove forest, namely in Muara Gembong. In coastal areas of mangrove forests found valid mangrove species consisting of 23 species (Gpswisataindonesia.info, 2016). Mangrove plants from the Bekasi - Muara Gembong coastal area are one of them, which can be made into a motif design that can later become a distinctive marker of Bekasi. The potential of the mangrove forest, if scrutinized and analyzed for grouping and looking for its unique essence elements, can be used as a theme in the creation of Motif Design. An example of a region that has a distinctive motif to mark origin authentication is Pekalongan. Pekalongan with Jlamprang motifs - typical round arrangement like Chinese kepeng coins combined with Indian patola motifs. Historically, because Pekalongan was a trading port on the north coast of Java, there was a lot of acculturation of Chinese and Indian cultures, which were later adopted into Pekalongan's typical Jlamprang motifs.

Starting from this problem, we will initiate a project to assist in creating a design motif/pattern design with the theme Muara Gembong Mangrove Forest, through graphic design training for students of Tunas Jakasampurna Vocational High School, Bekasi, majoring in multimedia. Furthermore, the creation of these products will be tested into product prototypes such as paper bags, pillowcases, T-Shirts with screen printing technology training or direct to print. These Vocational High School students are expected to act as motivators for Bekasi MSME products and even encourage the creation of new products from Bekasi MSME players.

The objectives of this community service are:

- Creating new, unique, creative, and innovative batik motifs based on the theme of the Muara Gembong mangrove forest, Bekasi, through graphic design training for students of Tunas Jakasampurna Vocational High School, Bekasi.;

- Provide training in screen printing and direct to print graphics to apply the creation of new batik motifs into prototyping products.

The benefits of this community service are:

- Vocational High School students will gain an enriched understanding and direct practice of creating Motif Design through the Design Thinking stage, Critical Thinking analysis of the potential of mangrove plants which are then searched for unique visual essences to sketch Motif Design/Visual Pattern Design. 
- Vocational High School students get Practical Knowledge, wherein the second stage the three best Motif Designs are selected, then taught starting from a sketch basis then poured into digital assets, which can later be applied as motifs for Fashion Products and apparel through Screen Printing \& DTG Print training.

Mangroves are a type of forest that grows along tidal mudflats and along with coastal areas of shallow water that extend inland along rivers, creeks, and tributaries whose water is generally salty (Melana et al., 2000).

According to Gustami (2007), the method of creation used in making works of art consists of three stages: exploration, design, and embodiment. The exploration stage is carried out by collecting library data, then collecting visual reference data from catalogs that approach the concept of this work and can be used as a comparison work. The design stage, which is built based on the acquisition of essential points from the formulated analysis, is continued to visualize ideas, namely in the form of alternative sketches. The best sketch options are determined as a design reference or with technical drawings that are useful for their realization. The embodiment stage starts from making a model according to an alternative sketch or technical drawing that has been prepared to become a prototype model until the perfection of the desired work is found.

A motif is a design made from parts of shapes, various kinds of lines or elements and is influenced by the form of natural stylization, objects with their own style and characteristics (Suhersono, 2004). In the batik craft, there are two known batik elements, namely: Ornament, which is the central motif as the dominant element in batik motifs, and Isen, which is a filler motif as a complementary element in batik motifs (Lisbijanto, 2013).

According to Lisbijanto (2013), batik patterns and motifs can be divided into three motifs, namely:

1) Geometric motifs, geometric batik motifs are batik motifs whose ornaments are geometric arrangements.

2) Non-geometric motifs, which include motifs in the form of humans, animals, and plants.

3) Inanimate object motifs include symbols in the form of water, fire, clouds, rocks, mountains, and the sun.

Several things that influence the creation of batik motifs are fauna, flora, the natural world (Rini et al., 2020).

\section{METHOD}

The community service method uses the Direct Coaching \& Monitoring method through mentoring and training in creating motif designs for students of Jakasampurna Vocational High School, Bekasi, majoring in multimedia. They consisted of nine people, namely Filiphy Raninda Rikin, Zanetha Keisha Rafikhalila, Naomi Monalisa Pranata, Dandy Antariksa, Bintang Pramuditha, Pamela KP, Shaqueille Shaugi M, Aqmal and Mahardika. They are given design reinforcement \& training, including:

1. Introduction to Design Thinking \& Critical Thinking Analysis

2. Motif Sketch through Morphological Metrix design analysis

3. Curate the results of Motif Design (chosen the best five from Vocational High School students)

4. Digitalization Design

5. Prototype training through screen printing \& direct to garment technology: the best one selected to be sampled in this training

The activity is carried out from April 2021 to August 2021, due to the pandemic, activities are carried out online, except for prototype training through screen printing technology \& direct to the garment, which is carried out offline with a health protocol. This training is also assisted by two Visual Communication Design students, namely Fellicia Angelique and Afreza Ardiansyah, who will assist in the process of knowledge transfer and preparation both online and offline.

\section{RESULT AND DISCUSSION}

Starting in April 2021, we will collect data on potential types of mangroves for the Motif Design (Desk Research) asset. From the available data, it is known that the types of mangrove plants in Muara Gembong, Bekasi Regency consist of 23 species (Gpswisataindonesia. info, 2016) which are dominated by Api-api (Avicennia spp.), Mangrove (Rhizophora spp.), Pedada (Sonneratia caseolaris). Then examined from the type of mangrove plant, which has the criteria that the plant has the characteristics of the environment, namely uniqueness, has an aesthetic, symbol of the region's product. Then we made direct observations of the object to be studied, by collecting all the leaves, clumps of leaves, stalks, flowers, twigs, and others using recording media, in the form of cameras and videos. Based on the criteria to be studied, namely, unique, never existed, artistic, then mapped based on the group or parts of the object obtained, namely groups of leaves, flowers, and roots. The selected objects were then observed and formulated for further use as material for training for students of Jakasampurna Vocational High School students, Bekasi, majoring in multimedia.

Furthermore, they were given design reinforcement \& training, including: preliminary design thinking \& critical thinking analysis, motif sketches through morphological metric design analysis, curation of motif design results, where the five best designs were selected from vocational students, digitalization design, and prototype training through screen printing technology \& direct to garment, where the best one is chosen to be sampled in this training

\section{Introduction to Design Thinking \& Critical Thinking Analysis}


At this stage, students are given an understanding that the method of creation used in making works of art has three steps. Starting from the exploration stage by collecting library data and from catalogs that approach the concept of creation, then the design stage is the choice of the best sketch as a design reference or with technical drawings that are useful for its embodiment, and the embodiment stage is from an alternative illustration that has been prepared into a prototype model until the desired perfection of the work is found. The training was conducted online to nine students.

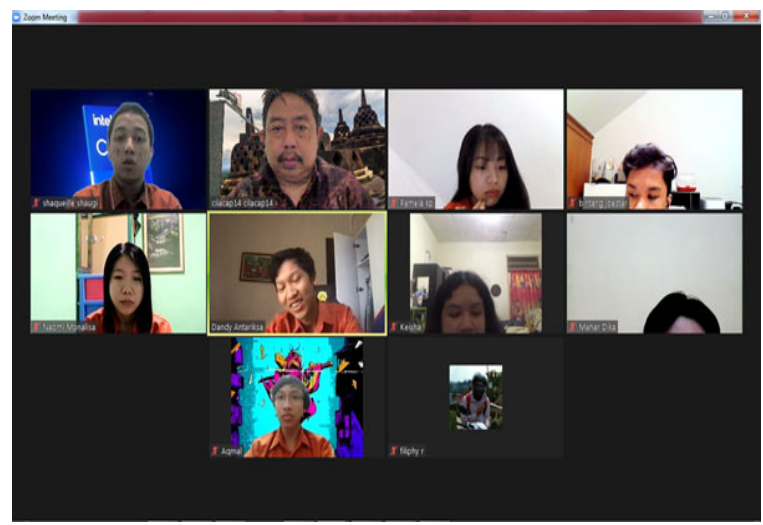

Picture 1. Briefing for design thinking and critical thinking analysis through zoom meeting

Implementation of Motive Design Training (Design Thinking and Motif Sketch)

At this stage, students are taught to sketch motifs based on the understanding conveyed in the previous step that in making a work of art it goes through three stages, based on the criteria to be studied, namely, unique, never existed, artistic based on groups of leaves, flowers, and roots. Next is given an example of the stages in the creation of a motif sketch. The training is conducted online.
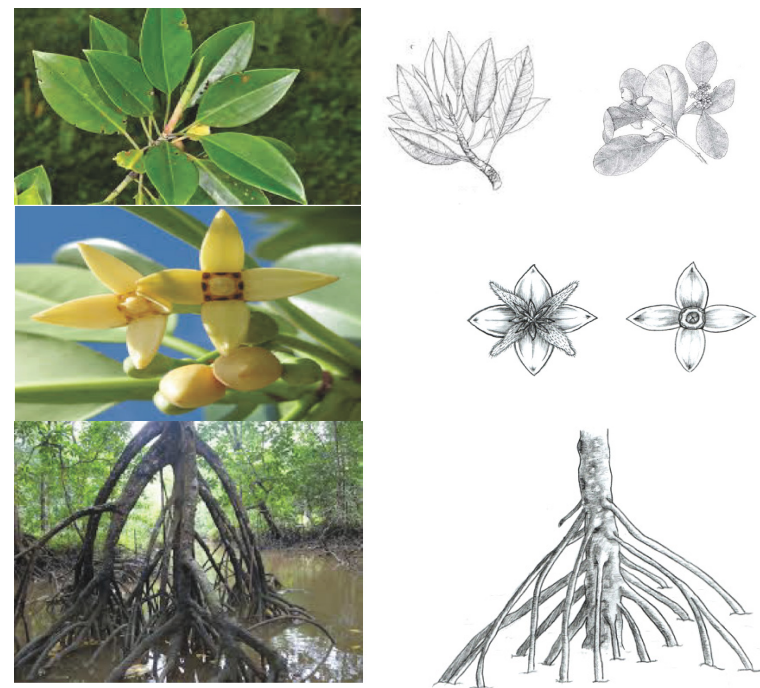

Picture 2. Example mapping of research objects: leaves, flowers, and roots

The object that has been selected artistically is made a basic sketch, using several alternative objects to get the desired visual. And the basic sketch is selected as a reference for the following process

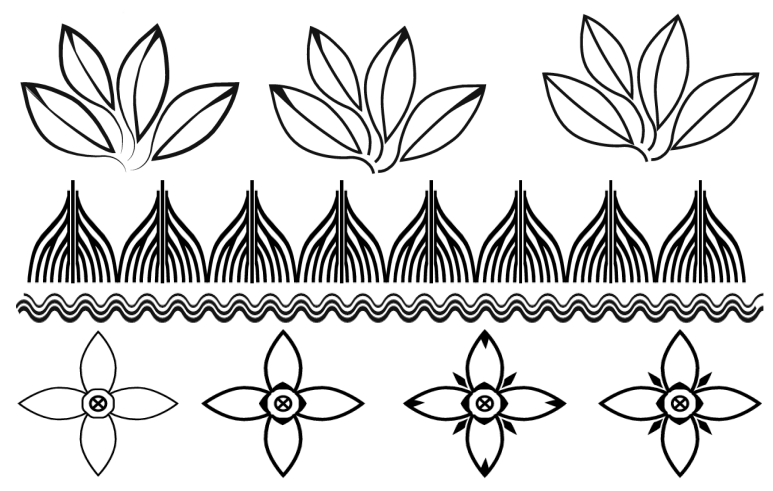

Picture 3. Example basic sketch: leaves, flowers, and roots

From the results of this training, students were asked to sketch their own motifs and then present them at the next meeting.

\section{Curation of Motif Design Results}

At this stage, the students presented their sketch of the motif of their work and then curated their work by the community service team and two accompanying students. Of the nine students who attended the training in the previous stage, only six people presented their work, namely Filiphy Raninda Rikin, Zanetha Keisha Rafikhalila, Naomi Monalisa Pranata, Dandy Antariksa, Bintang Pramuditha, and Pamela KP. This stage is done online.
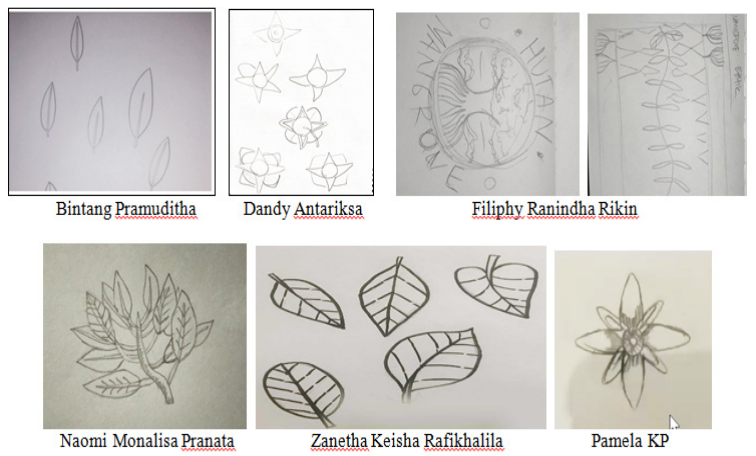

Picture 4. Student work sketch

The best five were selected from the six sketches created by the students. The best five were selected, namely the work of Filiphy Raninda Rikin, Zanetha Keisha Rafikhalila, Naomi Monalisa Pranata, Dandy Antariksa, and Bintang Pramuditha, then curated their work

\section{Digitalization Design}

After curating the community service team and two students, then the digitalization design of the five selected works was carried out.

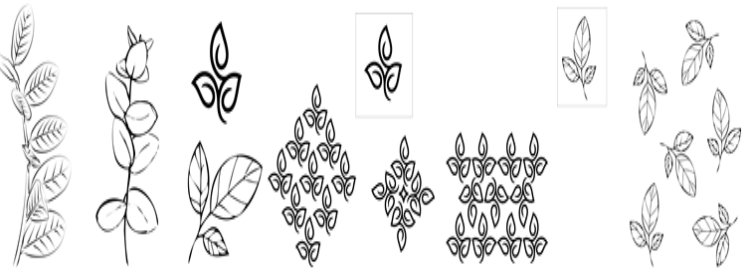

Picture 5. Digitalization design of Naomi Monalisa Pranata work 


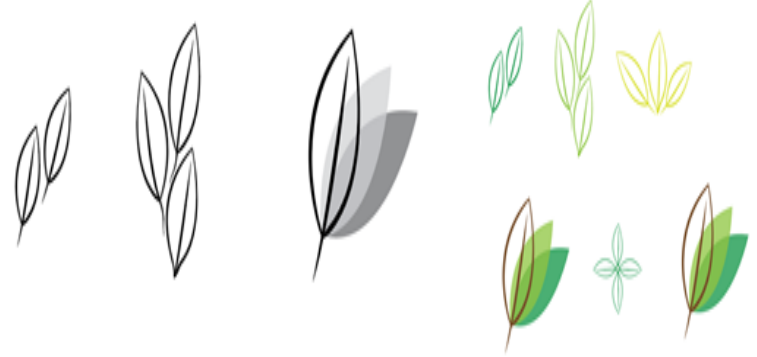

Picture 6. Digitalization design of Bintang Pramuditha work
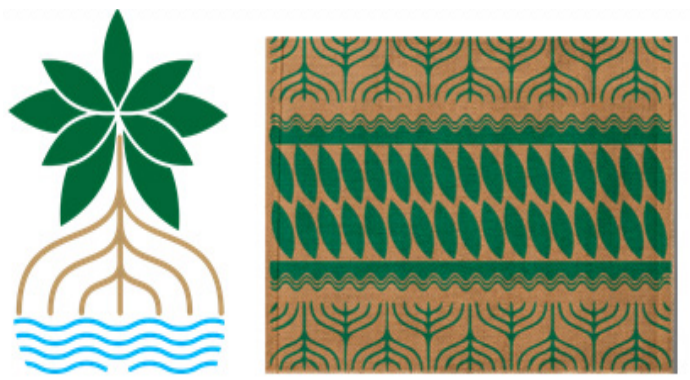

Picture 7. Digitalization design of Filiphy Ranindha Rikin work
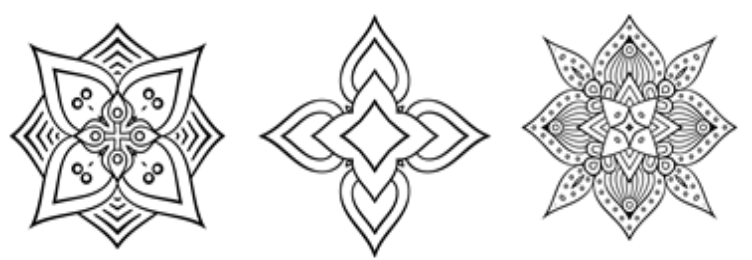

Picture 8. Digitalization design of Dandy Antariksa work
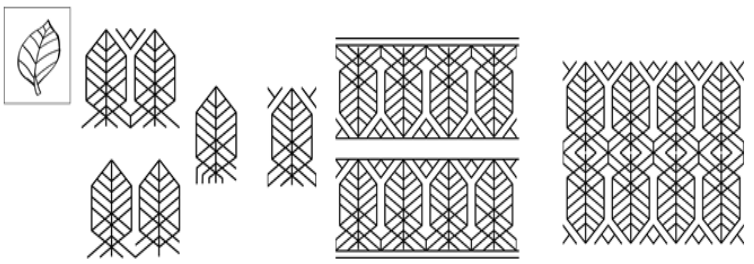

Picture 9. Digitalization design of Zanetha Keisha Rafikhalila work

One work was then selected from the five works to go to the next stage: prototype training through screen printing technology and direct to garment. The selected work is the work of Filiphy Raninda Rikin.

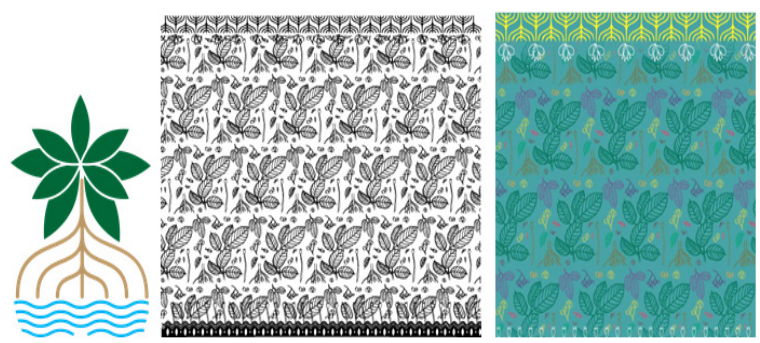

Picture 10. One work was selected of Filiphy Ranindha Rikin

Prototype Training through Screen Printing Technology and Direct to Garment

At this stage, the students are given training in the form of screen printing from the selected designs/designs into the shape of products or media applications such as T-shirts, paper bags, and fabrics,

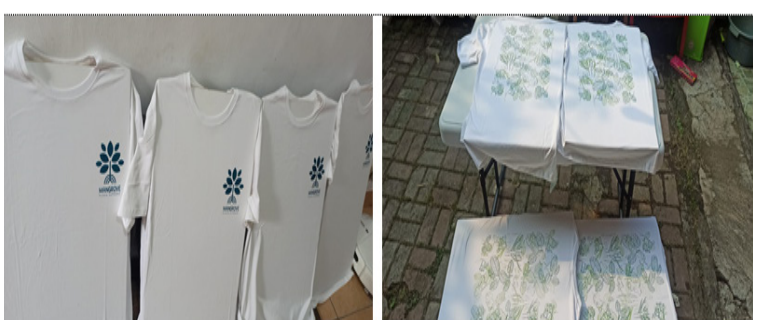

Picture 11. Screen printing technology directly to the T-Shirt

\section{CONCLUSION}

Based on the assistance to students of Tunas Jakasampurna Vocational High School, Bekasi, majoring in multimedia in the context of Community Service for four months, it was found that the students' works for batik motifs in Bekasi Regency were new, unique, creative, and innovative based on the theme of the Muara Gembong mangrove forest in the form of leaves, flowers, and roots. A total of five works were selected, and product prototype training through screen printing technology for the selected best rich. Furthermore, from mentoring the creation of motif designs through graphic design training, it is hoped that Vocational High School students will be the motivators for Bekasi MSME products and even encourage the innovation of new products from Bekasi MSME players.

\section{Acknowledgment}

The authors want to thank Bina Nusantara University. This research is supported by Community Service Grant for Appropriate Technology Bina Nusantara University, the year 2021.

\section{REFERENCES}

BPS Bekasi Regency. (2021). Gross Regional Domestic Product of Bekasi Regency by Industry 2016-2020. BPS Kabupaten Bekasi, Bekasi.

BPS Jawa Barat. (2021). Gross Regional Domestic Product (GRDP) of Jawa Barat Province by Industry 20162020. BPS Jawa Barat, Bandung.

Suhersono, H. (2004). Desain Bordir Motif Flora dan Dekoratif, Gramedia, Jakarta.

GPS Wisata Indonesia. (2016). Hutan Mangrove Muara Gembong Bekasi Jawa Barat. Retrieved January 20, 2021, from https:/gpswisataindonesia.info/hutanmangrove-muara-gembong-bekasi-jawa-barat/.

Melana, D.M., J. Atchue III, C.E. Yao, R. Edwards, E.E. Melana and H.I. Gonzales. (2000). Mangrove Management Handbook. Department of Environment and Natural Resources, Manila, Philippines through the Coastal Resource Management Project, Cebu City, Philippines.

Gustami, S.P. (2007). Butir-Butir Mutiara Estetika Timur, Ide Dasar Penciptaan Seni Kriya Indonesia. Prasista, Yogyakarta. 
Lisbijanto, H. (2013). Batik. Graha Ilmu, Yogyakarta.
Rini, D. R., Hidayat, I. K., Lose H., Y.A. (2020). “Designing Batik Motif with Digital Pattern Method." In International Conference on Art, Design, Education and Cultural Studies, KnE Social Sciences, 94-100. 